\title{
Transport of Toxic Elements through Leaching in and around Ash Disposal Sites
}

\author{
Shivam Kapoor and R. A. Christian
}

\begin{abstract}
In India coal-based thermal power plants have been a major source of power generation, where $75 \%$ of the total power obtained is from coal-based thermal power plants. These plants produce enormous quantity of fly ash. Many of the elements contained in ash are possessing health or environmental risks. In many applications, fly ash is exposed to natural fluids, such as acid rain and groundwater. A portion of fly ash produces by these plants is ultimately dumped in the ash dykes in the form of slurry. This slurry contain various metal ions out of which the ions of concern are $\mathrm{Hg}, \mathrm{Cr}, \mathrm{As}, \mathrm{Ni}, \mathrm{Cd}, \mathrm{Cu}$, $\mathrm{Pb}, \mathrm{Zn}$, and $\mathrm{B}$ which may percolate down \& pollute ground water.

This study investigates the leachate potential of heavy metal for fly ash of one of the Super Thermal Power Plant in India. It also studies the impact of leaching of toxics from ash dumps to water bodies within an area falling in $10 \mathrm{Km}$ radii of ash dumps. The results shows that 5-30\% toxic elements ( $\mathrm{As}, \mathrm{Cu}, \mathrm{Pb}, \mathrm{Mg}, \mathrm{Al}$ ) are leached in test and around $10 \%$ of total $\mathrm{Cd}$ was solubilized in the acidic $\mathrm{pH}$ range ( 3 to 5 ). This study also observed that some heavy metals, trace elements and fluoride in ground water and surface water are present in such quantity which is not desirable in drinking water for direct use as per WHO standards. Thus the study concludes that fly ash has moderate polluting effect on ground water in area which comes under radii of $4 \mathrm{Km}$ where proper treatment of water is required before utilizing it as a drinking purpose.
\end{abstract}

Index Terms-Coal, fly ash, leaching, toxic elements.

\section{INTRODUCTION}

The term 'coal' is believed to have originated from the Sanskrit world 'kaal', meaning black. In ancient time, coal was known as burning rock and was believed to possesses supernova power [1]. In India, unlike in most of the developed countries, ash content in the coal used for power generation is $30-40 \%$. In order after USSR, USA and China, India ranks fourth in the world in the production of coal ash as by-product waste [2]. Annually thermal power plants are generating about 112 million tons of fly ash as a byproduct of coal combustion in India [3]. The combustion of coal in thermal power plants may result in concentration of certain elements in fly ash, designated as enriched elements, such as $\mathrm{Cd}, \mathrm{Cr}, \mathrm{Pb}$, and $\mathrm{Zn}$. These elements have a greater tendency to leach out from the solid phase (fly ash). These toxic trace elements display subsequent enrichment in concentration from coal to bottom ash and to fly ash [4]. Fly ash contains oxides of aluminium and iron, feldspars, quartz, mullite,

Manuscript received December 17, 2014; revised May 4, 2015.

Shivam Kapoor is with Pandit Deendayal Petroleum University, Gandhinagar, Gujarat, India (e-mail: shivamkpr@yahoo.com).

R. A. Christian is with Sardar Vallabhbhai National Institute of Technology, Surat, Gujarat, India (e-mail: rac@ced.svnit.ac.in). gypsum and organic fractions like coke and char particles. Fly ash is enriched in most elements that are found in coal except for the most volatile elements, such as $\mathrm{Hg}$ [5]. Initially when fly ash comes in contact with water, the alkaline elements present on its surface will tend to dissolve rapidly and move into solution. But, with subsequent increase in solution $\mathrm{pH}$ and element concentration, reprecipitation of elements may occur to form more stable secondary solids [6]. Oxyanions like B, As and Se have high solubility and so these tend to leach more at both low and high $\mathrm{pH}$ values, while cations like $\mathrm{Ca}$ and $\mathrm{Sr}$ show decrease in solubility when $\mathrm{pH}$ increases [7]

The inorganic portion of coal is composed of various elements in a variety of mineral forms. During combustion, these elements may volatilize, oxidize, react with other elements, undergo heat dependent rearrangement of the mineral lattice or change in physical form. Many of the elements contained in ash are considered health or environmental risks; however, the magnitude of the risk from release of elements from fly ash is not well quantified. In many applications, fly ash is exposed to natural fluids, such as acid rain, groundwater, and acid mine drainage. Rate of release of various elements from fly ash has not been quantified in generally applicable terms. Disposal of huge amounts of fly ash in landfills, and surface impoundments or its reuse in construction materials is of environmental concern [8]. Some elements contained in fly ash are likely to be released from the storage/disposal/application site when ash comes in contact with water. These elements can be leached in higher concentrations than drinking water standards and can cause contamination in drinking water sources (pollute both ground and surface waters). Fly ash contains trace amounts of toxic metals that may have negative effects on soil, human and plants [9].

\section{MATERIALS AND METHODS}

Site: Thermal Power Plant has installed capacity of 2600MW. Coal which is used in power plant has following specification: Fixed Carbon - 42\%, Ash - 37\%, Volatile Material $-18 \%$, Moisture - 3\%, Gross Calorific Value $3800-4500 \mathrm{kcal} / \mathrm{kg}$. Annual ash production in plant is 36.5 lakh tonnes. Here, $53.41 \%$ ash is utilized and rest of the $46.59 \%$ is pumped in a slurry form through pipe lines to the ash pond located near the plant which is about $5 \mathrm{~km}$ away from the power station.

Sampling: For this study, 9 types of samples were taken which include samples from plant, nearby ash pond and villages around ash pond. For analyzing toxic impact of leaching in water bodies near the ash dumps, 26 samples of ground water and 9 samples of surface were collected from 
the villages falling in $10 \mathrm{Km}$ radii of ash ponds. For ground water sampling 5 villages in $3 \mathrm{Km}$ radii, 10 villages in 3-6 Km radii and 11 villages in $6-10 \mathrm{Km}$ radii were selected. For surface water 7 samples were taken from villages and 2 samples from nearby River.

Chemicals and glassware: All chemicals and reagents used were of the analytical grade (>99\% purity, Loba Chemicals, India) and distilled water obtained from the distillation unit was used for preparation and dilution of reagents. All the glasswares used were made of borosilicate glass. They were properly cleaned prior to use in experiments. The glassware washing protocol involves washing glassware with laboratory detergent to remove sample or solvent residues. Then all glasswares were kept overnight in chromic acid. They were rinsed thoroughly with tap water followed by distilled water. After washing, the glasswares were dried in an oven at $100^{\circ} \mathrm{C}$.

Metal Determination: Fly Ash and water samples collected from the ground as well as surface water sources in the vicinity of ash disposal sites and in radii of $10 \mathrm{Km}$ were analysed for heavy metal (As, $\mathrm{Ni}, \mathrm{Hg}, \mathrm{Cd}, \mathrm{Pb}, \mathrm{Mn}, \mathrm{Cr}, \mathrm{Cu}, \mathrm{Zn}$, $\mathrm{Co}, \mathrm{Al}, \mathrm{Fe}, \mathrm{B})$ concentration on Atomic Absorption Spectroscopy (AAS). All the water and fly ash samples were analysed for Flouride as $\mathrm{F}$ concentration by SPADNS colorimetric method (APHA) which is based on the reaction between fluoride and a zirconium-dye lake [10].

Leaching Test: Column Test method (Meteoric Water Mobility Procedure (MWMP)) was selected for carrying out the leachate study, since it is best suitable to know the short-term effect of leaching. Before proceeding for the test fly ash samples, collected at each stage, were mixed to get a homogeneous mixture. In all cases the moisture was maintained below $0.25 \%$. Particle size varies from coarse sand to fine silt and remains below $3 \mathrm{~mm}$ size.

\section{RESULTS AND DISCUSSION}

Leaching test was performed by Meteoric Water Mobility Procedure for $\mathrm{Cd}$, Total Chromium, $\mathrm{Ni}$, As, Pb, Zn, Mg, Al, F and $\mathrm{Cu}$. Test was performed with variation in $\mathrm{pH}$ and temperature. The concentrations of the heavy metals that were leached out with meteoric water as a result of column leaching test are shown in Table I. Chromium and Nickel did not leach from the fly ash samples because initially they were not present in fly ash and bottom ash samples as shown in Table II. Fluoride, Arsenic, Magnesium and Zinc showed solubility with water and was leached in higher concentration at acidic $\mathrm{pH}$ and higher temperature. The leached $\mathrm{Cu}$ concentration was low in comparison with As and $\mathrm{Zn}$, this is probably because $\mathrm{Cu}$ is precipitated as it's insoluble hydroxides. Around $10 \%$ of total $\mathrm{Cd}$ was solubilized in the acidic $\mathrm{pH}$ range. The elements in the ash particles were mainly associated with the surface, and these surface-associated fractions might dominate the leachate chemistry at the early stages of fly-ash disposal in contact with water [11]. However, the elements incorporated within the interior of the fly ash dissolved at a slower rate compared with the readily leachable surface associated elements.

Aluminium, Nickel, Magnesium, Manganese and Fluoride data was analysed for ground water samples in ArcMAP 10.1 software (ArcGIS) with the help of Kriging interpolation method. Kriging is a group of statistical techniques to interpolate the value of a random field (e.g., the elevation, $z$, of the landscape as a function of the geographic location) at an unobserved location from observations of its value at nearby locations.

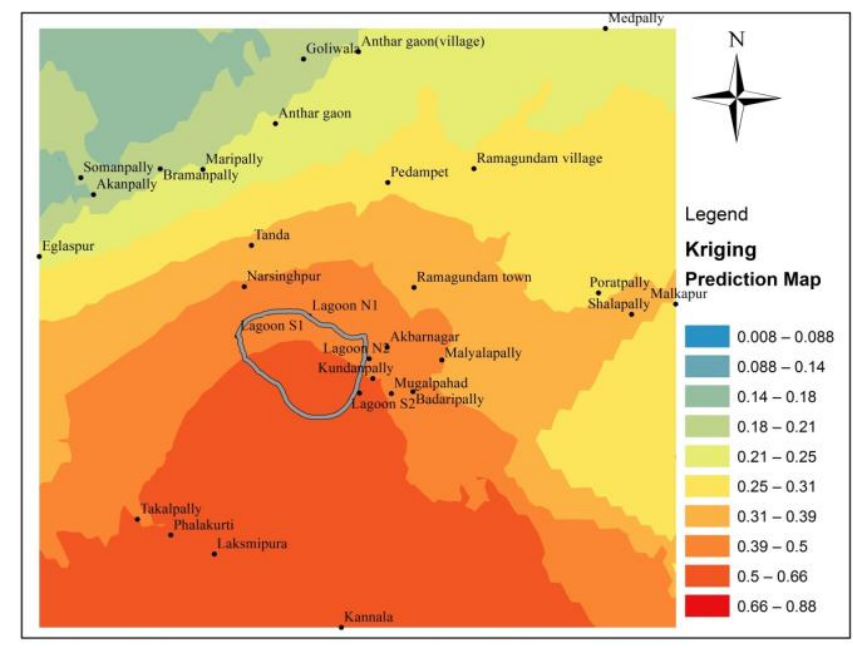

Fig. 1. Concentration contour for Aluminium in ground water.

Contour map for Aluminium in ground water samples is showed in Fig. 1. Grey colour polygon is representing fly ash lagoon. Concentration of Aluminium near polygon is high. In north-west direction concentration of metal is decreasing with increase in distance and in south direction concentration of metal is increasing with increase in distance. Movement of underground water in south direction may be the reason high concentration of Aluminium in south-west zone.

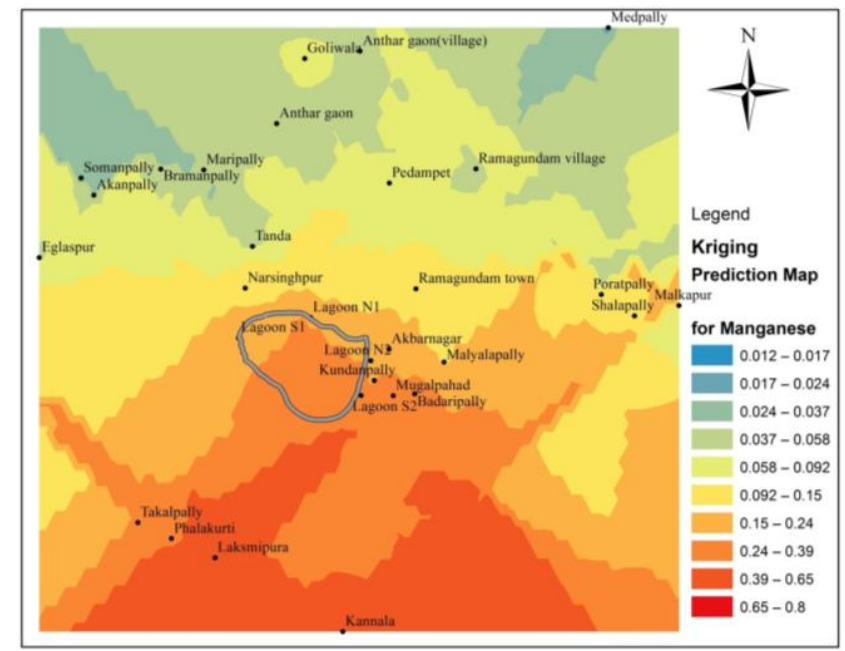

Fig. 2. Concentration contour for Manganese in ground water.

Contour map for Manganese in ground water samples is showed in Fig. 2. Grey colour polygon is representing fly ash lagoon. Concentration of Manganese near polygon is moderate in range of $0.15-0.39 \mathrm{mg} / \mathrm{L}$. In north direction concentration of metal is decreasing with increase in distance except 1 sample and in south direction concentration of metal is increasing with increase in distance. Movement of underground water in south direction may be the reason high concentration of Manganese in south-west zone.

Fig. 3 is showing contour map for Fluoride in ground water samples. Grey colour polygon is representing fly ash lagoon. 
Concentration of Fluoride near polygon is high in range of $0.94-1.3 \mathrm{mg} / \mathrm{L}$. In north direction concentration of metal is decreasing with increase in distance except 2 sample and in south direction concentration of metal is increasing with increase in distance. Movement of underground water in south direction may be the reason high concentration of Manganese in south-west zone.

TABLE I: LEACHING RESUlTS OF FLY ASH (BDL: BELOW DETECTION LIMIT)

\begin{tabular}{|c|c|c|c|c|c|c|c|c|c|c|c|}
\hline \multirow{3}{*}{$\begin{array}{l}\text { Sr. } \\
\text { no }\end{array}$} & \multirow{3}{*}{ Parameters } & \multirow{3}{*}{ Unit } & \multicolumn{9}{|c|}{ Leachate Analysis } \\
\hline & & & \multicolumn{3}{|l|}{$\mathrm{pH} 5.5$} & \multicolumn{3}{|l|}{$\mathrm{pH} 6.5$} & \multicolumn{3}{|c|}{$\mathrm{pH} 8.5$} \\
\hline & & & $28^{\circ} \mathrm{C}$ & $30^{\circ} \mathrm{C}$ & $34^{\circ} \mathrm{C}$ & $28^{\circ} \mathrm{C}$ & $30^{\circ} \mathrm{C}$ & $34^{\circ} \mathrm{C}$ & $28^{\circ} \mathrm{C}$ & $30^{\circ} \mathrm{C}$ & $34^{\circ} \mathrm{C}$ \\
\hline 1 & Cadmium & $\mathrm{mg} / \mathrm{L}$ & 0.085 & 0.1 & 0.11 & BDL & 0.03 & 0.07 & $\begin{array}{c}\text { BDL } \\
\end{array}$ & BDL & BDL \\
\hline 2 & Chromium & $\mathrm{mg} / \mathrm{L}$ & BDL & BDL & BDL & BDL & BDL & BDL & BDL & BDL & BDL \\
\hline 3 & Nickel & $\mathrm{mg} / \mathrm{L}$ & BDL & BDL & BDL & BDL & BDL & BDL & BDL & BDL & $\mathrm{BDL}$ \\
\hline 4 & Arsenic & $\mathrm{mg} / \mathrm{L}$ & 1.21 & 1.72 & 1.92 & 0.42 & 0.68 & 0.75 & BDL & BDL & BDL \\
\hline 5 & Lead & $\mathrm{mg} / \mathrm{L}$ & 0.97 & 1.21 & 1.18 & 0.48 & 0.61 & 0.65 & 0.07 & 0.09 & 0.03 \\
\hline 6 & Zinc & $\mathrm{mg} / \mathrm{L}$ & 3.25 & 3.6 & 3.9 & 1.05 & 1.05 & 1.08 & 0.22 & 0.26 & 0.28 \\
\hline 7 & Magnesium & $\mathrm{mg} / \mathrm{L}$ & 3.85 & 3.96 & 4.1 & 1.35 & 1.4 & 1.45 & 0.27 & 0.3 & 0.32 \\
\hline 8 & Aluminium & $\mathrm{mg} / \mathrm{L}$ & 1.50 & 1.87 & 2.10 & 0.36 & 0.72 & 0.86 & BDL & BDL & BDL \\
\hline 9 & Fluoride & $\mathrm{mg} / \mathrm{L}$ & 3.96 & 4.40 & 4.92 & 0.98 & 1.30 & 1.26 & BDL & BDL & BDL \\
\hline 10 & Copper & $\mathrm{mg} / \mathrm{L}$ & 0.03 & 0.07 & 0.08 & 0.06 & 0.08 & 0.08 & 0.03 & 0.04 & 0.06 \\
\hline
\end{tabular}

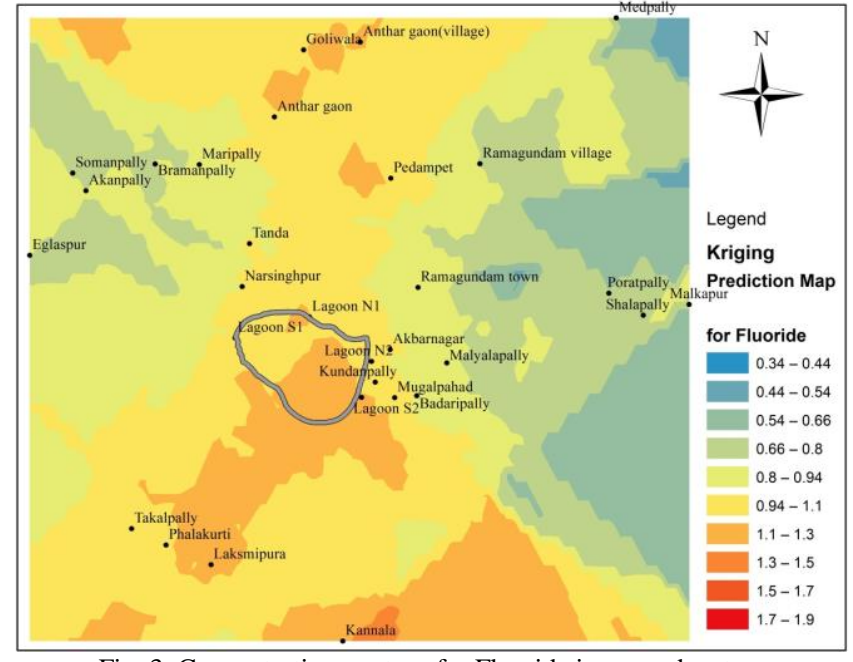

Fig. 3. Concentration contour for Fluoride in ground water.

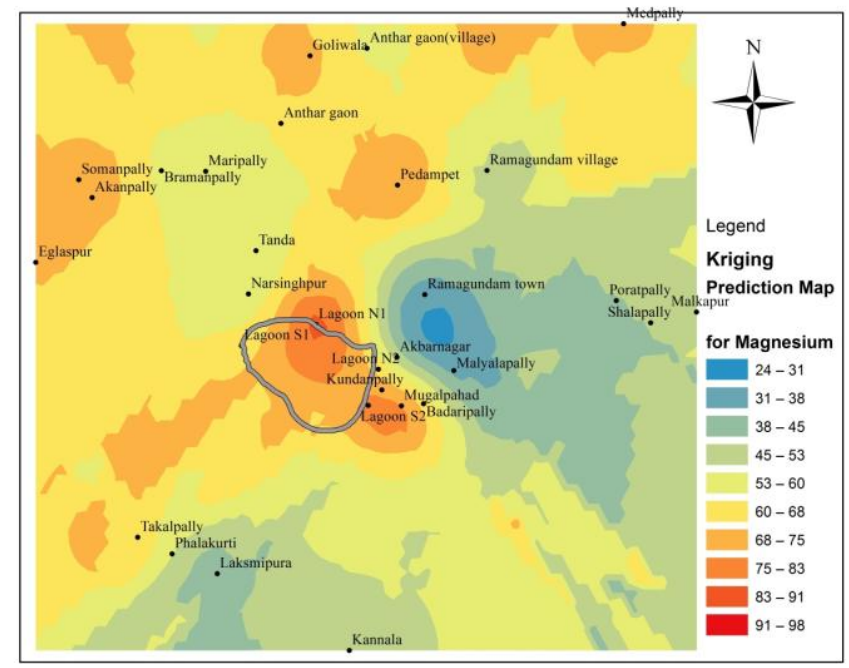

Fig. 4. Concentration contour for Magnesium in ground water.

Fig. 4 is showing contour map for Magnesium in ground water samples. Grey colour polygon is representing fly ash lagoon. Concentration of Magnesium near polygon is high in range of $68-83 \mathrm{mg} / \mathrm{L}$. In north direction concentration of metal is increasing with increase in distance and in south and east direction concentration of metal is decreasing with increase in distance. Villages near fly ash lagoons are highly polluted than other samples.
Contour map for Nickel in ground water samples is showed in Fig. 5. Grey colour polygon is representing fly ash lagoon. Concentration of Nickel near polygon is very high in range of 0.11-0.30 $\mathrm{mg} / \mathrm{L}$. In north-east and north-west direction concentration of metal is decreasing with increase in distance except 1 sample and in south direction concentration of metal is also decreasing with increase in distance.

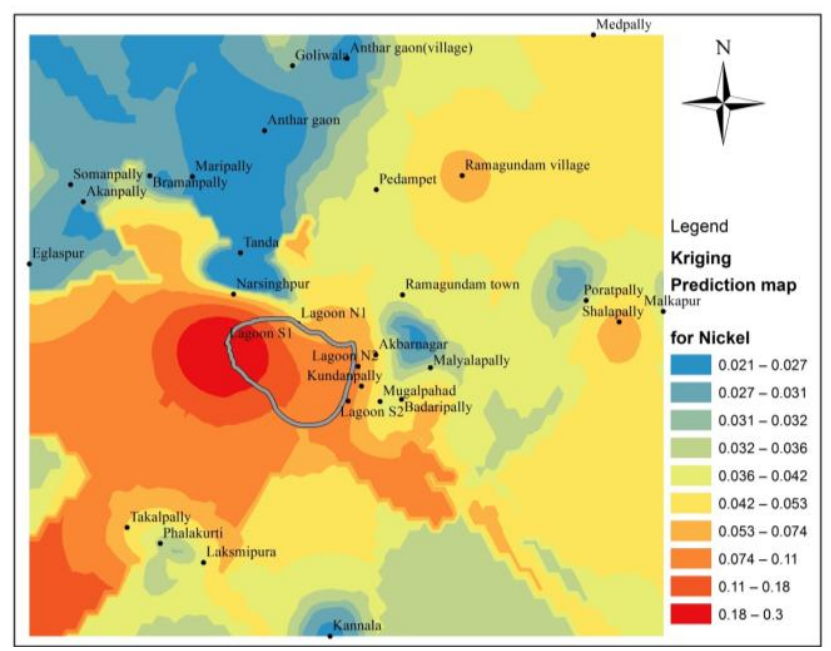

Fig. 5. Concentration contour for Nickel in ground water.

Presently ash pond lining is not being followed in practice on fly ash lagoon sites. Therefore, the possibility of leaching of the heavy metals increases. Since soil below the impoundments is always saturated and under considerable hydraulic head, the inefficiently lined ponds provide a great opportunity for the groundwater contaminants to seep in. Therefore seepage from ash ponds may be more compared to leaching from landfills and ash mounds. In addition to this, discharge of rain water and run off from the ash mound areas into surface water bodies can also be a source of water pollution. Therefore it is necessary to incorporate ash pond lining while designing ash ponds. Planting of saplings having tolerance to warm slurry water and heavy metals is considered to be the most ideal mitigation measure, since the biomass can also adsorb toxic metals as nutrients and provide obstruction for windblown particulates.

On the other hand dry collection of fly ash allows its better utilization. The disposal of unutilized ash in the form of ash 
mound not only saves the use of land and water but minimizes the chances of water pollution, by minimizing leaching. However proper measures like lining at the bottom of the ash mound, stabilization of ash mound and covering of the completed mound with vegetation are required to minimize environmental damage.

TABLE II: HeAvy Metals Concentration In FLy Ash AND BotTom Ash

\begin{tabular}{lllll} 
Sr. No. & Parameters & Unit & Fly ash & Bottom ash \\
& & & & \\
\hline \hline 1 & Fluoride as $\mathrm{F}$ & $\mathrm{mg} / \mathrm{kg}$ & 40 & 45 \\
\hline 2 & Cadmium as Cd & $\mathrm{mg} / \mathrm{kg}$ & 1.88 & 1.79 \\
\hline 3 & Cobalt as Co & $\mathrm{mg} / \mathrm{kg}$ & 18.84 & 11.58 \\
\hline 4 & Chromium as $\mathrm{Cr}$ & $\mathrm{mg} / \mathrm{kg}$ & BDL & BDL \\
\hline 5 & Copper as Cu & $\mathrm{mg} / \mathrm{kg}$ & 0.238 & 0.078 \\
\hline 6 & Manganese as $\mathrm{Mn}$ & $\mathrm{mg} / \mathrm{kg}$ & 39.82 & 26.1 \\
\hline 7 & Magnesium as $\mathrm{Mg}$ & $\mathrm{mg} / \mathrm{kg}$ & 56.6 & 70.2 \\
\hline 8 & Nickel as $\mathrm{Ni}$ & $\mathrm{mg} / \mathrm{kg}$ & $\mathrm{BDL}$ & BDL \\
\hline 9 & Lead as $\mathrm{Pb}$ & $\mathrm{mg} / \mathrm{kg}$ & 12.34 & 10.04 \\
\hline 10 & Zinc as Zn & $\mathrm{mg} / \mathrm{kg}$ & 35.12 & 25.4 \\
\hline 11 & Arsenic as As & $\mathrm{mg} / \mathrm{kg}$ & 25.2 & 29.7 \\
\hline 12 & Mercury as $\mathrm{Hg}$ & $\mathrm{mg} / \mathrm{kg}$ & 40.2 & 19.3 \\
\hline 13 & Selenium as $\mathrm{Se}$ & $\mathrm{mg} / \mathrm{kg}$ & BDL & BDL \\
\hline 14 & Beryllium as Be & $\mathrm{mg} / \mathrm{kg}$ & 10.8 & 5.6 \\
\hline 15 & Barium as Ba & $\mathrm{mg} / \mathrm{kg}$ & BDL & BDL \\
\hline 16 & Lithium as $\mathrm{Li}$ & $\mathrm{mg} / \mathrm{kg}$ & BDL & BDL \\
\hline 17 & Boron as B & $\mathrm{mg} / \mathrm{kg}$ & 7.53 & 3.76 \\
\hline \hline
\end{tabular}

\section{CONCLUSION}

Ashes produced by coal thermal power plants are considered as a waste and need to be properly disposed to avoid environmental contamination, so it is important to know the leaching potential of toxic elements in ash and its transport The following conclusions can be made from this study:

1) The results shows that 5-30\% toxic elements ( $\mathrm{As}, \mathrm{Cu}, \mathrm{Pb}$, $\mathrm{Mg}, \mathrm{Al}$ ) are leached in test and around $10 \%$ of total $\mathrm{Cd}$ was solubilized in the acidic $\mathrm{pH}$ range.

2) Area comes under radii of $4 \mathrm{Km}$ is highly polluted in terms of ground water which required proper treatment before utilizing it as a drinking purpose.

3) Transport of heavy metals through the leaching around the ash disposal site is matter of concern for governing authorities

\section{REFERENCES}

[1] A. Sharan, A. Sharma, and P. Govind, "Impact of coal mining on social ecology - A tentative note," Socio-Economic Impact of Environment, New Delhi, India: Akashi Publishing House, pp. 46-65.
[1] M. R. Senapati, "Fly ash from thermal power plants - waste management and overview," Current Science, vol. 100, no. 12, pp. 1791-1794, 2011

[2] S. Dhadse, P. Kumari, and L. J. Bhagia, "Fly ash characterization, utilization and Government initiatives in India - A review," J. Sci. Ind. Res., vol. 67, pp. 11-18, 2008.

[3] A. Baba, "Leaching characteristics of wastes from Kemerkoy," Global Nest: the International Journal, vol. 2, no. 1, pp. 51-57, 2000.

[4] X. Gong, T. Wu, Y. Qiao, and M. Xu, "In situ leaching of trace elements in a coal ash dump and time dependence laboratory evaluation," Energy Fuels, vol. 24, pp. 84-90, 2010.

[5] R. S. Gandhi, "Design and maintenance of ash pond for ash disposal," IGC-2005, Ahmedabad, India, pp. 85-90, 2005.

[6] L. Ruhl, A. Vengosh, G. S. Dwyer, H. Hsu-Kim, and A. Deonarine, "Environmental impacts of the coal ash spill in Kingston, Tennessee: an 18-month survey," Environmental Science and Technology, vol. 44, pp. 9272-9278, 2010.

[7] R. Piekos and S. Paslawska, Leaching characteristics of fluoride from coal fly ash," Fluoride, vol. 31, pp.188-192, 1998.

[8] A. Mehara, M. E. Farago, and D. K. Banerjee, "Impact of fly ash from coal fired power stations in Delhi, with particular reference to metal contamination," Environ. Monit. Assess., vol. 50, pp. 15-35, 1998.

[9] APHA, AWWA and WEF, Standard methods for the examination of wastewater, 20th edition, American Public Health Association, American Water Works Association, and Water Environmental Federation, Washington. D.C, 1998.

[10] S. K. Choi, S. Lee, Y. K. Song, and H. S. Moon, "Leaching characteristics of selected Korean fly ashes and its implications for the groundwater composition near the ash mound," Fuel, vol. 81, pp. 1083-1090, 2002.

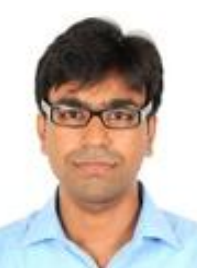

Shivam Kapoor was born in Uttar Pradesh, India in 1988. He has graduated with distinction in environmental engineering from Uttar Pradesh Technical University, in 2010 and an M.Tech in environmental engineering from Sardar Vallabhbhai National Institute of Technology, Surat in 2014.

$\mathrm{He}$ is presently employed as a lecturer with the Dept. of Civil Engineering, School of Technology, PDPU. Mr. Kapoor has about six months of industrial experience and about two years of research experience. Formerly he was employed as a project associate in environmental engineering and management, the Department of Civil Engineering, Indian Institute of Technology Kanpur, India. Prior to joining research, he was employed for six months as an environmental engineer in Clover Organic Pvt. Ltd., Dehradun, India.

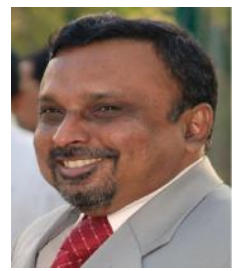

Robin A. Christian obtained his B.E. in civil engineering from BVM College of Engineering, Vallabh Vidyanager, Gujarata India. He obtained his Ph.D from SVR College of Engg. and technology, Surat, Gujarat, India. He is an associate professor at SV National Institute of Technology, Surat, Gujarat, India. He is recognized the Ph.D guide at the same institute. He is handling the research project from the Department of Automic Energy and Nuclear Science. His area of interest is biological treatment processes and air pollution and control. 